\title{
Gene Expression of Trehalase during Post-dormant Development of the Brine Shrimp, Artemia: Comparison of the Two Species
}

\author{
Ziro NAMBU, Shin TANAKA and Fumiko NAMBU \\ Biology, Department of Medical Technology I, School of Health Sciences, University of \\ Occupational and Environmental Health, Japan. Yahatanishi-ku, Kitakyushu 807, Japan
}

Abstract: Based on a homology screening approach, two degenerate oligonucleotides were employed as primers in a polymerase chain reaction to amplify a fragment of DNA encoding trehalase with a template of cDNA derived from embryos of American Artemia. Sequence analysis revealed that the fragment was composed of 228 bp comprising 76 amino acids, and highly homologous to trehalases of Tenebrio molitor (mealworm beetle), rabbit, Caenorhabditis elegans, Bombyx mori (silkworm) and Escherichia coli treA and treF (58-38\%, in order of description). This fragment was used as a hybridization probe. A Northern blot analysis on American Artemia showed three transcripts of $5.0,2.7$ and $2.2 \mathrm{~kb}$, and the two larger transcripts were also detected in Chinese Artemia. The developmental profile of the gene expression and the trehalase activity suggest that the transcripts of 5.0 and (or) $2.7 \mathrm{~kb}$ in both Artemia may be directly or indirectly related to translation of the trehalase. A Southern blot analysis on both Artemia suggested the existence of two highly homologous genes or one gene having an intron within the region where the probe binds in their haploid genome.

Key words: trehalase, gene expression, brine shrimp, Artemia.

(Reccived 13 August 1997, accepted 22 October 1997)

\section{Introduction}

The brine shrimp, Artemia, is known as a cryptobiotic organism, which enters an encysted state of dormancy at the gastrula stage embryo. The dormant cyst contains trehalose, accounting for $15 \%$ of its dry weight [1]. Such an amount of trehalose is thought to be necessary for the organism to be tolerant against cold, desiccation and vacuum during its dormancy.

The dried encysted embryo resumes development on rehydration and adequate salinity under an aerobic condition, coinciding with a decrease in the 
content of trehalose accompanied by a corresponding increase in the level of glycogen and glycerol. Thus, the trehalose is thought to be a respiratory substrate $[2,3]$.

The enzymatic hydrolysis of the trehalose is due to the activity of the trehalase ( $\alpha, \alpha$-trehalose glucohydrolase, EG 3.2.1.28) and it was investigated in detail during the course of post-dormant development of American Artemia [4]. The trehalase activity of American Artemia is unchanged until the emergence of the stage $\mathrm{E}-1$ prenauplius (at $6 \mathrm{hr}$ of the culture), followed by a 10 fold increase in its activity coinciding with the peak of the emergence of the stage E-2 prenauplius (at $12 \mathrm{hr}$ of the culture). The level of the trehalase activity decreased thereafter, and half of the maximal activity remained in the nauplius incubated for $30 \mathrm{hr}$.

To elucidate in greater detail the biosynthesis and molecular nature of the trehalase, we obtained a cDNA fragment of Artemia trehalase and investigated the developmental change of trehalase gene expression during the post-dormant stage. A Southern blot analysis was also carried out. We compared these data between American and Chinese Artemia.

\section{Materials and Methods}

Animals

Two species of Artemia were used in our experiments. The dried dormant cysts of Artemia from the Great Salt Lake in Utah, USA and from China were purchased from Japan Pet Drugs Co. (Tokyo and Los Angeles, CA). Rearing conditions of the dormant cysts of American Artemia have been described elsewhere [4]. Chinese Artemia was incubated in the same way except for using 3\% $\mathrm{NaCl}$ instead of $2 \% \mathrm{NaCl}$ as for the American one.

\section{Enzyme Assay}

Trehalase activity was measured as described previously [4].

\section{Oligonucleotides as Primers for Polymerase Chain Reaction (PCR)}

Based on a homology screening of the $\mathrm{C}$-terminal region of the known trehalases of rabbit small intestine [5], Tenebrio molitor (mealworm beetle) [6], Bombyx mori (silkworm) [7, 8], Caenorhabditis elegans [9], and Escherichia coli treA [10], two degenerate oligonucleotides were designed to amplify a supposedly conserved C-terminal region of Artemia trehalase. The sense primer and the antisense primer used are shown in Fig. 1. 


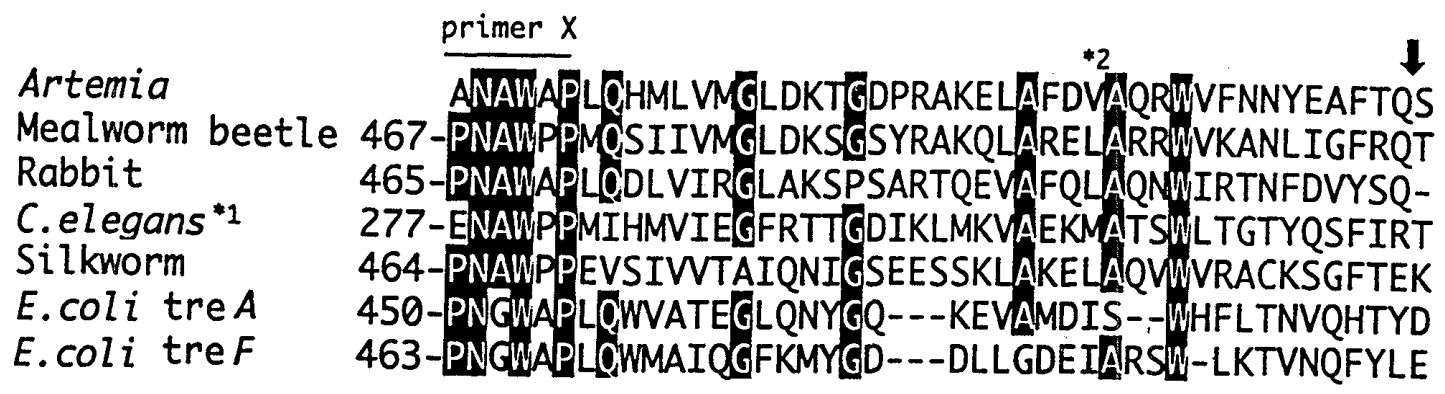

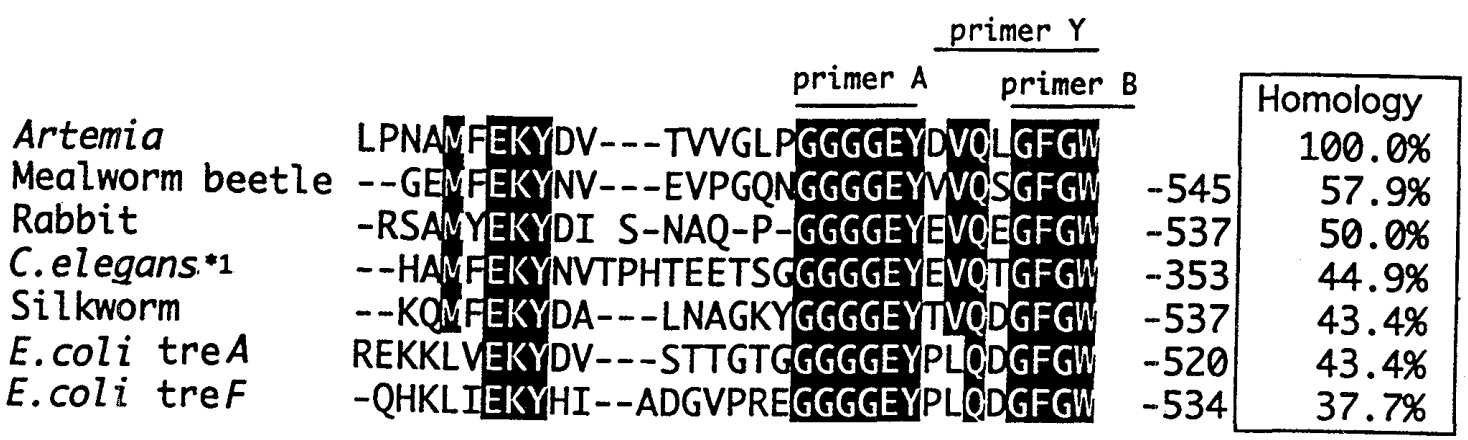
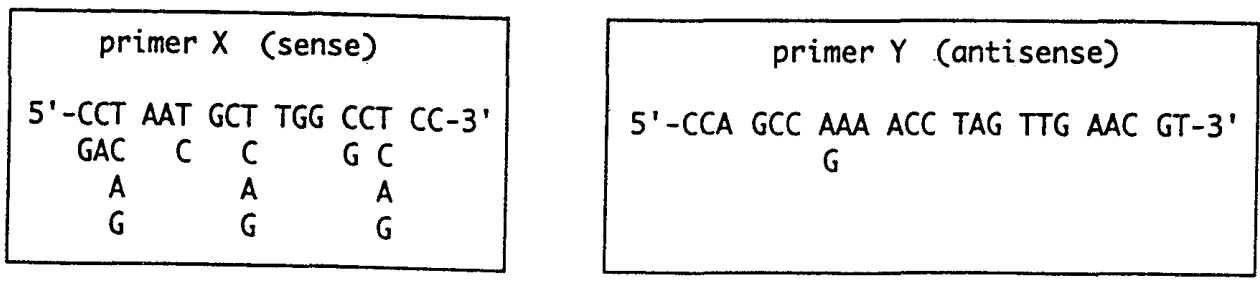

Fig. 1. Oligonucleotide primers used in PCR and the deduced amino acid sequence of the 228 bp cDNA fragment aligned with those of trehalases of $T$. molitor (mealworm beetle), rabbit, $C$. elegance, B. mori (silkworm), $E$. coli tre $A$ and treF. Sense and antisense primers were designed by a homology screening approach on trehalases of rabbit [5], T. molitor [6], B. mori [7, 8], C. elegans [9] and E. coli tre $\Lambda$ [10]. At first, 6 degenerate primers were designed and used in PCR, but only one cDNA fragment of $47 \mathrm{bp}$ was obtained using the primer $\mathrm{A}$ and $\mathrm{B}$. After nucleotide sequencing of 4 inserts subcloned into pBluescript $\mathrm{SK}(-)$, a primer $\mathrm{Y}$ (antisense primer) was defined by the identity of 4 inserts. The primer $\mathrm{Y}$ and a newly synthesized degenerate primer $\mathrm{X}$ (sense primer) were introduced in PGR to obtain a larger cDNA fragment. The obtained 228 bp fragment was subcloned into the plasmid, and 5 inserts were sequenced. Identical amino acids are reversed in the alignment. * 1: Only a partial fragment of its trehalase is submitted in GenBank [9]. *2: One amino acid exchange, $\mathrm{V}$ or $\mathrm{L}$ (frequency, 3GTT/2GTT). $\downarrow$ : Hind III cleavage site.

\section{PGR Amplification}

Total RNA was prepared from 7.5-hr cultured American Artemia embryos by the method of Maniatis $e t a l$. [11] and $0.5 \mu \mathrm{g}$ of it were used for first strand cDNA synthesis. The whole reaction mixture was then subjected to the PCR mixture (TaKaRa RNA PGR Kit ver. 2). PGR amplification of 30 cycles was performed with $10 \mu \mathrm{M}$ each of the primers using $94^{\circ} \mathrm{C} / 1 \mathrm{~min}$ for denaturing, $55^{\circ} \mathrm{C} / 1$ min for annealing, and $72^{\circ} \mathrm{C} / 1$ min for primer extension. A part of 
the resulting product was again amplified under the same conditions because of its small quantity. The amplification was performed with a DNA thermal cycler (Perkin Elmer Cetus). The resulting products were separated on a 3\% agarose (NuSieve ${ }^{\circledR}$ GTG Agarose, TaKaRa) gel, and a 228 bp fragment was isolated. This fragment was subcloned into the EcoR V site of pBluescript SK $(-)$ (Stratagene).

Sequencing and Analysis of the cDNA Fragment

DNA sequences of 5 inserts were determined by the dideoxy chain termination method [12] using the Thermo Sequenase fluorescent labeled cycle sequencing kit (Amersham) adapted to a 373 DNA Sequencer (Applied Biosystems). All inserts were sequenced completely on both strands, and they all proved to be identical except for one base at their center region, resulting in a change of one amino acid (Fig. 1). The amino acid sequence deduced from the fragment of trehalase cDNA was compared with amino acid sequence data base SWISS-PROT using the FASTA program.

Northern Blot

All of the RNA was extracted from both Artemia whole embryos and larvae at different culture times as described above in the PCR Amplification section. For blot analysis, about $20 \mu \mathrm{g}$ of aliquot from the total RNA were electrophoresed on a $1 \%$ agarose gel with formaldehyde, transferred to Hybond- $\mathrm{N}^{+}$ nylon membrane (Amersham) [11], and fixed by baking at $120^{\circ} \mathrm{C}$ for $25 \mathrm{~min}$. As a hybridization probe, the subcloned PCR fragment was labeled with digoxigenin in PGR containing $2 \mu \mathrm{M}$ each of definite primers based on the nucleotide sequence analysis, $160 \mu \mathrm{M}$ each of dATP, dCTP, dGTP, $104 \mu \mathrm{M}$ dTTP, $56 \mu \mathrm{M}$ digoxigenin-11-dUTP (Boehringer Mannheim), $1.5 \mathrm{mM} \mathrm{MgGi}{ }_{2}$, $10 \mathrm{mM}$ Tris-HCl, pH 8.3, $50 \mathrm{mM} \mathrm{KCl}$ and 1 unit of TaKaRa Taq (TaKaRa). The blotted RNAs were hybridized with the labeled probe at $68^{\circ} \mathrm{C}$ and washed at $65^{\circ} \mathrm{C}$, and the probe hybridized was detected by the antibody (AntiDigoxigenin-AP, Fab fragment, Boehringer Mannheim) and chemiluminescent substrate ( CSPD ${ }^{\circledR}$, Boehringer Mannheim) [13].

Southern Blot

Genomic DNA was prepared from more than 48-hr cultured nauplii of both Artemia by the method of Yamada et al. [14]. Aliquots of $8 \mu \mathrm{g}$ of the DNA were digested separately with 27 units of EcoR I, Hind III, and BamH I for $15 \mathrm{hr}$, at $37^{\circ} \mathrm{C}$. The digests were separated on a $0.7 \%$ agarose gel and blotted onto a Hybond- $\mathrm{N}^{+}$nylon membrane [15]. All the following procedures necessary for hybridization and detection were performed as mentioned above 
in the Northern Blot section.

\section{Results and Discussion}

Characterization of the cDNA fragment of Artemia trehalase

Sequence analysis showed that the obtained cDNA fragment was composed of $228 \mathrm{bp}$. It was deduced to encode 76 amino acids. A computer-assisted research revealed no significant similarity in the fragment to any other protein except for trehalases of several species (Fig. 1). The rate of identical residues with $T$. molitor (mealworm beetle) [6], rabbit [5], C. elegans [9] $B$. mori (silkworm) [7, 8], and E. coli treA [10] and treF [16] were 57.9-37.7\% (Fig. 1). We could not compare the fragment with that of human trehalase, because $\mathrm{N}-$ and $\mathrm{C}$-terminal regions of the human trehalase have not yet been isolated [17]. The obtained fragment had less similarity with trehalases of Candida albicans (33.3\%) [18], Kluyveromyces lactis (33.3\%) [19] and Saccharomyces cereviciae (yeast) YBR0106 (NTH2) (33.3\%) [20, 21, 22] and NTH1 (31.3\%) [23, 24], especially in the region where the primer $\mathrm{Y}$ might bind. The sequence of the fragment resembles those of higher eukaryotes and bacteria, but differs somewhat from fungi. These results indicate that the cDNA fragment really encodes the $\mathrm{C}$-terminal region of the trehalase of Artemia, one of the crustacean.

Analysis of trehalase gene expression

Results of Northern blot analysis on the total RNA from whole embryos and larvae from both Artemia are shown in Fig. 2. The probe clearly hybridized to RNAs of 2.7 and $2.2 \mathrm{~kb}$ at $0 \mathrm{hr}$ of the culture on American Artemia, followed by the appearance of a $5.0 \mathrm{~kb}$ RNA from $6 \mathrm{hr}$ to $30 \mathrm{hr}$, maximized at $12 \mathrm{hr}$. The smallest RNA diminished early in the postdormant development. Chinese Artemia expressed two RNAs of 2.7 and 5.0 $\mathrm{kb}$, which were detected from $6 \mathrm{hr}$ and $30 \mathrm{hr}$ of the culture, respectively (Fig. 2). The contents of the $18 \mathrm{~S}$ rRNA from both species increased gradually during their developments (Fig. 2).

The change in the activity of the trehalase during the post-dormant development, as described in the Introduction, suggests the significance of the $5.0 \mathrm{~kb}$ transcript in American Artemia.

The activity of the trehalase in the development of Chinese Artemia was unchanged until $10 \mathrm{hr}$ of the culture, and gradually increased, reaching a plateau of 5 fold increase in its activity between $30-40 \mathrm{hr}$ of the culture (data not shown). The difference in the developmental profile of the trehalase activity between American and Chinese Artemia might be due to the low hatchability and poor synchronism of Chinese Artemia [4]. The developmental 


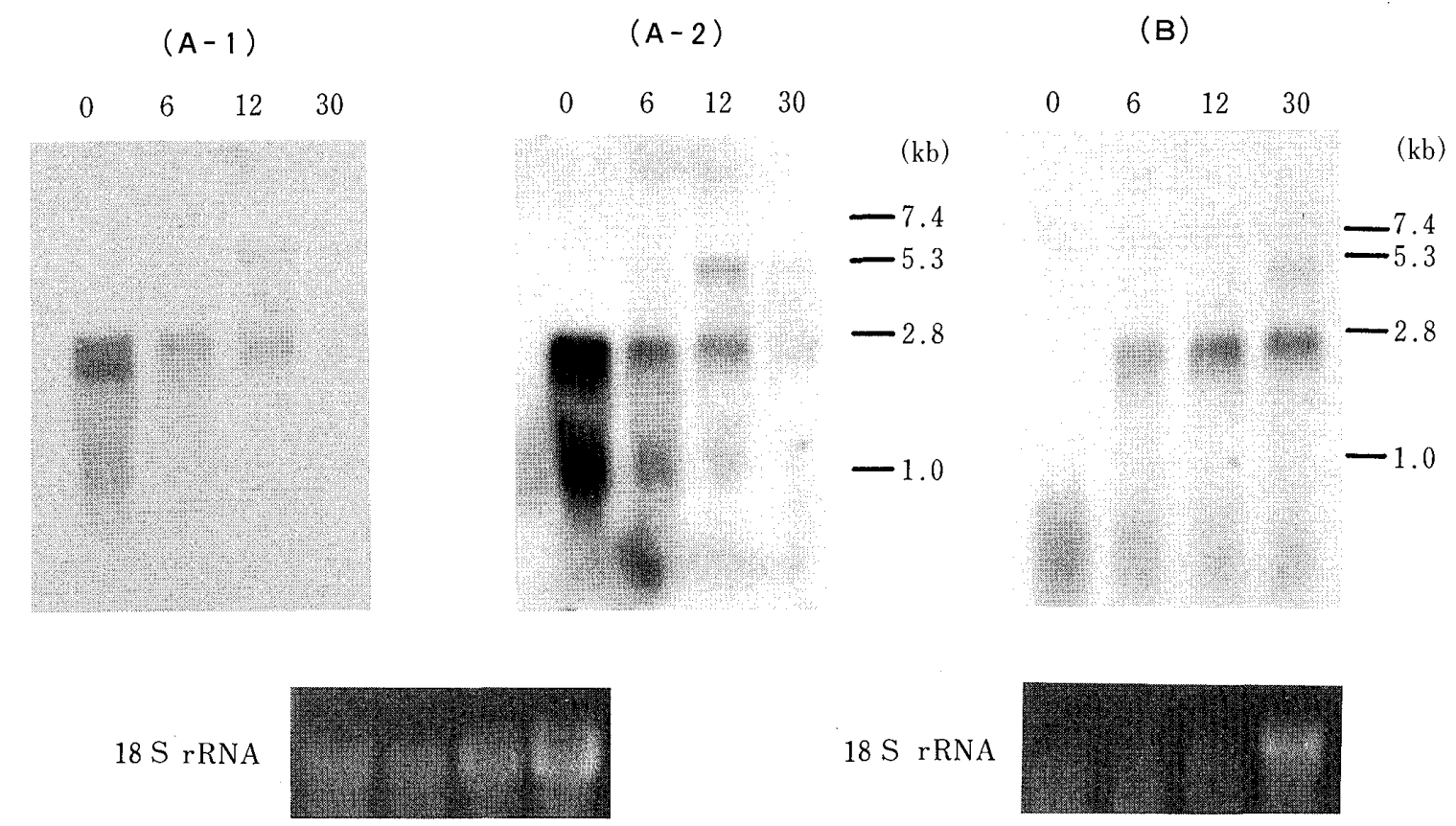

Fig. 2. Developmental profile of Artemia trehalase gene expression. Northern blot analysis and the ethidium bromide-stained $18 \mathrm{~S}$ rRNA of American (A-1, A-2) and Chinese (B) Artemia are shown. RNAs extracted from both Artemia whole embryos and larvae at different times in culture were hybridized with the 228 bp probe labeled with digoxigenin and chemiluminously detected by the antibody. (A-1) and (A-2) show results obtained by a shorter exposure and a longer exposure, respectively. Digoxigenin-labeled molecular markers (RNA Molecular Weight Marker I, Boehringer) were used on the gel.

profile of the trehalase activity in Chinese Artemia well correlated with the appearance of the $2.7 \mathrm{~kb}$ transcript in Chinese Artemia.

The molecular mass of the enzyme trehalase was reported to be $70 \mathrm{kDa}$ in both Artemia, and Endoglycosidase $\mathrm{H}$ digestion of the trehalase resulted in a molecular mass of $66 \mathrm{kDa}$ on SDS-PAGE [4]. This means that mRNA for the trehalase may be equal to or longer than $2 \mathrm{~kb}$. All of the transcripts detected were in agreement with this condition.

Newly synthesized transcripts in the post-dormant development of American Artemia were the $5.0 \mathrm{~kb}$ RNA, and the RNAs of 2.7 and $5.0 \mathrm{~kb}$ in Chinese Artemia. The size of the larger transcript in Chinese Artemia, which was detected rather later, corresponded to that of the newly synthesized RNA in American Artemia. The size of the smaller transcript in Chinese Artemia corresponded to the larger transcript already present at $0 \mathrm{hr}$ of the culture on American Artemia. These suggest a possibility for both Artemia that the $5.0 \mathrm{~kb}$ RNA is a precursor mRNA, which is usually undetectable but detectable around the maximal level of transcription, and that the $2.7 \mathrm{~kb}$ RNA, which is relatively stable, is the mature mRNA molecule for the trehalase. However, a great deal of the $2.7 \mathrm{~kb}$ transcript at $0 \mathrm{hr}$ of the culture on American Artemia is 
incomprehensible.

Reported sizes of mRNA for trehalase, numbers of encoded amino acids and molecular mass of the mature trehalase are as follows: human, $2 \mathrm{~kb}, 75$ $\mathrm{kDa}$ [17]; rabbit, $1.9 \mathrm{~kb}, 578$ aa, $65 \mathrm{kDa}$ [5, 25]; T. molitor, $2.0 \mathrm{~kb}, 555 \mathrm{aa}, 62$ $\mathrm{kDa}[6,26]$; B. mori, $3.0 \mathrm{~kb}, 579$ aa, $70 \mathrm{kDa}$ [7, 8]; Escherichia coli treA, 565 aa, $58 \mathrm{kDa}$ [10]; E. coli treF, 549 aa, $64 \mathrm{kDa}$ [16]; Artemia, $70 \mathrm{kDa}$ [4].

The role of the transcript of $2.2 \mathrm{~kb}$ at $0 \mathrm{hr}$ of the culture on American Artemia is not clear at present. It is plausible that it might be a degradation product of the transcripts of 5.0 and $2.7 \mathrm{~kb}$ or a processed transcript which has other functions than trehalase.

Southern Blot Analysis

Genomic DNAs from whole nauplii of both Artemia were digested with

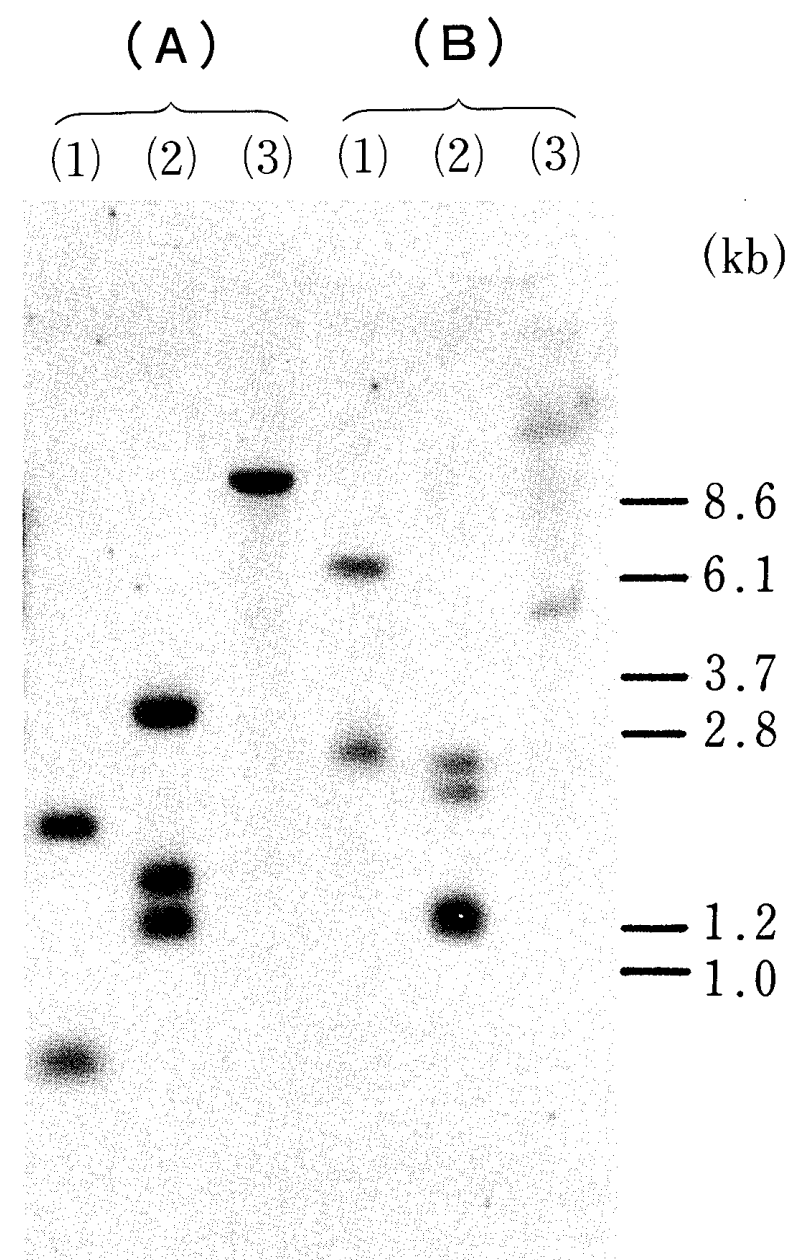

Fig. 3. Southern blot analysis of trehalase gene. DNA from American (A) and Chinese (B) Artemia nauplii digested with EcoR I (1), Hind III (2), and Bam H I (3) restriction enzyme was hybridized with the $228 \mathrm{bp}$ probe labeled with digoxigenin, and chemiluminously detected by the antibody. Digoxigenin-labeled molecular markers (DNA Molecular Marker VII, Boehringer) were used on the gel. 
$E c o$ R I , Hind III, and BamH I restriction enzyme, respectively, and used in a Southern blot analysis to examine the complexity of the gene. The probe carries one Hind III cleavage site (Fig. 1), but no sites for $E c o \mathrm{R} \mathrm{I}$ and $B a m \mathrm{H}$ I . As shown in Fig. 3, EcoR I and Hind III digestions gave two and three DNA fragments, respectively, on both Artemia. Bam $\mathrm{H}$ I gave one fragment on American Artemia and two fragments on the Chinese one. These results are consistent with the idea for both Artemia that the trehalase gene is unique and has one intron which is on a region where the probe binds, or two highly homologous trehalase genes exist. Quotations described in the next paragraph are not contrary to the probability of the above idea and give perspective to the complexity of the trehalase gene.

The genetic and biochemical analyses of Drosophira trehalase indicated that soluble and membrane bound trehalases are manifestations of a single protein encoded by a single gene [27]. A single copy of the trehalase gene was reported to be present in the haploid genome of $B$. mori, expressing two types of mRNA, each of which is for soluble and membrane bound trehalase $[7,8]$. The Southern blot analysis of rabbit genomic DNA suggested that there exist(s) three genes or one gene with two introns in its haploid genome [5]. In $S$. cerevisiae (yeast), the neutral trehalase gene named NTH1 was reported to be on chromosome IV and a putative trehalase-encoding gene named YBR0106 (NTH2) was also reported to be on chromosome II. The amino acid sequence of the latter gene showed $77 \%$ identity with NTH1 [20, 21, 22]. Periplasmic trehalase is known to be homologous to cytoplasmic trehalase in $E$. coli, and they are coded by treA [10] and treF [16], respectively.

Experiments designed to isolate full length cDNA encoding Artemia trehalase are now under study. The results and discussion described above gave us perspectives for the coming experiments. Isolation of cDNA corresponding to Artemia trehalase will provide further insight into the biosynthesis and molecular nature of the enzyme as well as the phylogenetic origin of the enzyme and the regulation of the expression of the gene.

\section{References}

1. Clegg J S (1962): Free glycerol in dormant cysts of the brine shrimp, Artemia salina, and its disappearance during development. Biol Bull Woods Hole 123: 295-301

2. Clegg J S (1964): The control of emergence and metabolism by external osmotic pressure and the role of free glycerol in developing cysts of Artemia salina. J Ext Biol 41: 879-892

3. Ewing R D, \& Clegg J S (1969): Lactate dehydrogenase activity and anaerobic metabolism during embryonic development in Artemia salina. Comp Biochem Physiol 31: 297-307

4. Nambu Z, Nambu F \& Tanaka S (1997): Purification and characterization of trehalase 
from Artemia embryos and larvae. Zool Sci 14: 419-427

5. Ruf J, Wacker H, James P, Maffia M, Seiler P, Galand G, von, Kieckebusch A, Semenza G \& Mantei N (1990): Rabbit small intestinal trehalase. Purification, cDNA cloning, expression, and verification of glycosylphosphatidylinositol anchoring. J Biol Chem 265: $15034-15039$

6. Takiguchi M, Niimi T, Su Z-H \& Yaginuma T (1992) : Trehalase from male accessory gland of an insect, Tenebrio molitor. cDNA sequencing and developmental profile of the gene expression. Biochem $\mathrm{J}$ 288: 19-22

7. Su Z-H, Sato Y \& Yamashita O (1993) : Purification, cDNA cloning and Northern blot analysis of trehalase of pupal midgut of the silkworm, Bombyx mori. Biochim Biophys Acta 1173: $217-224$

8. Su Z-H, Ikeda M, Sato Y, Saito H, Imai K, Isobe M \& Yamashita O (1994): Molecular characterization of ovary trehalase of the silkworm, Bombyx mori and its transcriptional activation by diapause hormone. Biochim Biophys Acta 1218: 366-374

9. Somerville A C \& Behm C A (1996): only submitted in GenBank, ACGESSION: U51925

10. Gutierrez C, Ardourel M, Bremer E, Middendorf A, Boos W \& Ehmann U (1989): Analysis and DNA sequence of the osmoregulated treA gene encoding the periplasmic trehalase of Escherichia coli K12. Mol Gen Genet 217: 347-354

11. Maniatis T, Fitsch E F \& Sambrook J (1982) : Molecular cloning: A Laboratory Manual (1st ed). Cold Spring Harbor Laboratory, Cold Spring Harbor, New York 545 pp

12. Sanger F, Nicklen S \& Coulson R A (1977): DNA sequencing with chain termination inhibitors. Proc Natl Acad Sci USA 74: 5463-5467

13. Engler-Blum G, Meier M, Frank J \& Müller G A (1993): Reduction of background problems in nonradioactive Northern and Southern blot analyses enables higher sensitivity than ${ }^{32}$ P-based hybridization. Anal Biochem 210: 235-244

14. Yamada K, Akasaka K \& Shimada H (1989) : Structure of sea urchin arylsulfatase gene. Eur J Biochem 186: 405-410

15. Sambrook J, Fritsh E F \& Maniatis T (1989): Molecular cloning: A Laboratory Manual (3rd ed). Cold Spring Harbor Laboratory, Cold Spring Harbor, New York

16. Horlacher R, Uhland K, Klein W, Ehrmann M \& Boos W (1996): Characterization of a cytoplasmic trehalase of Escherichia coli. J Bacteriol 178: 6250-6257

17. Sasai-Takedatsu M, Taketani S, Nagata N, Furukawa T, Tokunaga R, Kojima $T$ \& Kobayashi Y (1996): Human trehalase: Characterization, localization, and its increase in urine by renal proximal tubular damage. Nephron 73: 179-185

18. Eck R, Bergmann B, Ziegelbauer K, Schoenfeld W \& Kuenkel W (1997): Molecular cloning and characterization of a gene coding for the neutral trehalase of Candida albicans. only submitted in GenBank, ACCESSION: X95099

19. Amaral F C, Dijck P V, Nicoli J R \& Thevelein J M (1997): Molecular cloning of the neutral trehalase gene from Kluyveromyces lactis and the distinction between neutral and acid trehalases. Arch Microbiol 167: 202-208

20. Wolfe K H \& Lohan A J E (1994): Sequence around the centromere of Saccharomyces cerevisiae chromosome II : Similarity of CEN2 to CEN4. Yeast 10: S41-S46

21. Nwaka S, Kopp M \& Holzer H (1995): Expression and function of the trehalase genes NTH1 and YBR0106 in Saccharomyces cerevisiae. J Biol Chem 270: 10193-10198

22. Feldmann H, Aigle M, Aljinovic $G$ et al. (1994): Complete DNA sequence of yeast chromosome II. EMBO J 13: 5795-5809 
23. Kopp M, Müller H \& Holzer H (1993): Molecular analysis of the neutral trehalase gene from Saccharomyces cerevisiae. J Biol Chem 268: 4766-4774

24. Kopp M, Nwaka S \& Holzer H (1994): Corrected sequence of the yeast neutral trehalase-encoding gene (NTH1): biological implications. Gene 150: 403-404

25. Galand G, L'Horset F, Longis Y \& Perret C (1995): Trehalase gene expression during postnatal development of rabbit intestine and kidncy: effects of glucocorticoids. Am J Physiol 269: G833-G841

26. Yaginuma T, Mizuno T, Mizuno C, Ikeda M, Wada T, Hattori K, Yamashita O \& Happ G M (1996): Trehalase in the spermatophore from the bean-shaped accessory gland of the male mealworm beetle, Tenebrio molitor: purification, kinetic properties and localization of the enzyme. J Comp Physiol B 166: 1-10

27. Melvin J O, Huber R E \& Williamson J H (1978): Genetic and biochemical aspects of trehalase from Drosophila melanogaster. Biochem Genet 16: 927-940

アルテミアの発生におけるトレハラーゼ遺伝子の発現：

2 種のアルテミアにおける比較

南部 滋郎, 田中 晋, 南部 文子

產業医科大学産業保健学部 第 1 生体情報学

要＼cjkstart旨： ホモロジーに基づいてプライマーを設計し，アメリカ産アルテミア肧のcDNA 鋳 型として PCR を行い，トレハラーゼ cDNAの断片を増幅した。得られた断片は $228 \mathrm{bp}$ で, 76 個のアミノ酸からなり，ゴミムシダマシ，ウサギ，C. elegans，カイコ および大腸菌のトレハラーゼに高い類似性 $(58-38 \%)$ を認めた。この断片をプロー ブとしてノーザンブロットしたところ，アメリカ産アルテミアでは 5.0，2.7 抢よび $2.2 \mathrm{~kb}$ の転写産物を, 中国産では前 2 者のみを検出した。トレハラーゼ活性と転写 産物の発生における変化を両アルテミアで比較検討した結果， 5.0 扔よび $2.7 \mathrm{~kb} の$ 産物がトレハラーゼの翻訳に直接または間接的に関与していると考えられた。サザ ンブロットの結果，雨アルテミアにハプロイドゲノムあたり 2 コピーの遺伝子が存 在寸るか，またはプローブ結合部位にイントロンのある1コピーのトレハラーゼ遺 伝子があると考えられた。

J UOEH（産業医大誌）19 (4)：255－264 (1997) 